\title{
DNA TYPING OF DESSERT BANANA CULTIVAR 'KOLIKUTTU' ('SILK') ACCESSIONS BY MICROSATELLITE MARKERS
}

\author{
HWL Pushpakumari $^{1 *}$, WLG Samarasinghe ${ }^{2}$, and SGJN Senanayake ${ }^{1}$ \\ ${ }^{1}$ Dept of Agricultural Biology, Faculty of Agriculture, University of Ruhuna, Mapalana, Kamburupitiya \\ ${ }^{2}$ Plant Genetic Resources Centre, Gannoruwa, Peradeniya
}

Accepted: $28^{\text {th }}$ September 2009

\begin{abstract}
Fourteen Kolikuttu accessions showing morphological variation and Fusarium wilt tolerance were collected. Extracted DNA was subjected to PCR using six SSR primers. PCR products were separated by PAGE and bands were visualized, scored and statistically analyzed using POPGENE 1.32 version to obtain the dendrogram by genetic distance matrix. Out of 19 SSR alleles amplified, 12 were polymorphic resulting in $63.16 \%$ loci polymorphism. Based on the dendrogram, three different 'Kolikuttu' accessions known as "Athdath Puwalu", the accession collected from Telijjawila, and accession collected from Angunakolapelassa were clustered separately. These three accessions could be considered as different genotypes.
\end{abstract}

Key words: DNA Typing, Dessert Banana, Cultivar Kolikuttu

\section{INTRODUCTION}

Banana belongs to the Genus Musa that is classified again into four recognized sections, namely Eumusa, Rhodochlamys, Australimusa, and Callimusa. Eumusa includes all species of true bananas (Chandraratna 1951). There is a wide range in cultivated or true bananas. In Sri Lanka, twenty nine banana cultivars and two wild species have been reported (Chandraratna \& Nanayakkara 1951). Five out of twenty nine cultivars are cooking types and the rest are dessert types. Dessert type, 'Kolikuttu' (Silk, Apple) may be originated in India and has $\mathrm{AAB}$ genome. Of the numerous fruit crops grown in Sri Lanka, banana is cultivated in about 48,000 ha contributing $46 \%$ of the total fruit production (AgStat 2004; Rajapakse et al. 2005). 'Kolikuttu 'is one of the highly prized fruit in Sri Lanka but is highly susceptible to Fusarium wilt disease (Panama wilt) (Rajapakse et al. 2005).

Study on the genotypic variation among individuals of a crop is the primary requirement for any crop improvement programme. To perform breeding programme it is essential to evaluate genetic variation if it is unknown. Therefore, it is necessary to evaluate genetic diversity of Kolikuttu germplasm in Sri Lanka to exploit genetic variation for desired characters such as Fusarium wilt tolerance. Simple Sequence Repeat (SSR) markers are routinely used for diversity analysis and molecular breeding in many crops because of their high level of polymorphism, co-dominant nature, efficiency and cost effectiveness. Microsatellite markers have been utilized for numerous applications in Musa (Crouch et al. 1998b). The experiment was carried out with the objectives to estimate the genetic di- versity of selected Kolikuttu accessions and to genotype selected Kolikuttu accessions.

The experiment was carried out at the Plant Genetic Resources Centre, Peradeniya, Sri Lanka from March to August 2008. Fourteen 'Kolikuttu' accessions were collected based on morphological variations and Fusarium wilt tolerance from different locations while an 'Ambul' accession was used as the control (Table 1). Immature unopened whitish colour banana cigar leaves were taken for DNA extraction.

DNA was extracted according to the CTAB (Centylmethyl Ammonium bromide) procedure (Weising et al. 1995), which was modified for $\mathrm{Mu}$ sa by Samarasinghe et al. (2001).

Three grams of each leaf samples were ground in liquid nitrogen until a fine powder was formed. The powder was transferred quickly into $15 \mathrm{ml}$ of pre-warmed $\left(60^{\circ} \mathrm{C}\right) \quad 4 \%$ CTAB extraction buffer with $0.1 \% \beta-$ mercaptoethanol. After incubating for $30 \mathrm{~min}$ at $60^{\circ} \mathrm{C}, 15 \mathrm{ml}$ of $24: 1$ Chloroform: Isoamyl alcohol was added and gently shaken for $20 \mathrm{~min}$. The solution was centrifuged at $5000 \mathrm{rpm}(10 \mathrm{~min})$ and supernatant was transferred to another autoclaved "Falcon" centrifuge tube. Then 0.6 volume of ice cold isopropanol was added and mixed gently by inverting. Precipitated DNA was spooled out and placed in an eppendorf tube and washed with washing solution (1M ammonium acetate and $70 \%$ ethanol). Mixture was centrifuged at 5000rpm for $10 \mathrm{~min}$. The washing solution was drained and DNA pellet was air dried. Pellet was dissolved in 100$500 \mu 1$ of TE buffer at $4^{0} \mathrm{C}$. Presence of DNA was confirmed on an agarose gel and stained with ethidium bromide. The extract was further purified from RNA by adding RNAse to $50 \mu \mathrm{g} / \mathrm{ml}$.

\footnotetext{
*Corresponding author:layanthi.agru2@gmail.com

Paper presented at the $2^{\text {nd }}$ National Symposium, Faculty of Agriculture, University of Ruhuna
} 
Table 1. Kolikuttu accessions used in the experiment and their collection sites [HORDI- Horticultural Research and Development Institute, PGRC- Plant Genetic Resources Centre]

\begin{tabular}{cllll}
\hline $\begin{array}{c}\text { Identity } \\
\text { no. }\end{array}$ & $\begin{array}{c}\text { Location of sample } \\
\text { collected }\end{array}$ & Original collection site (District) Vernacular name & Reason for collection \\
\hline 1 & HORDI & Divulapitiya (Gampaha) & Kolikuttu & To evaluate for Fusarium wilt disease tolerance \\
2 & HORDI & Halpitiya (Kegalle) & Kolikuttu & do \\
3 & HORDI & Sevanagala (Monaragala) & Kolikuttu & do \\
4 & HORDI & Embilipitiya (Ratnapura) & Kolikuttu & do \\
5 & HORDI & Embilipitiya (Ratnapura) & Kolikuttu & do \\
6 & PGRC & Embilipitiya (Ratnapura) & Idal Puwalu & Had lax bunches \\
7 & PGRC & Embilipitiya (Ratnapura) & Kutti Puwalu Had compact bunches \\
8 & PGRC & Siyambalanduwa (Monaragala) & Kotiyagala Type Had compact bunches \\
9 & PGRC & Puttlam (Puttlam) & Athdath Puwalu Had long fruits \\
10 & PGRC & Angunukolapalassa (Hambanthota) & Kolikuttu & Not affected by Fusarium wilt \\
11 & Telijjawila & Matara & "Agra" & Newly released variety and has not affected by \\
& & & Fusarium wilt over ten generations and no hard \\
12 & Telijjawila & Matara & Kolikuttu & Usmps formation in fruits \\
13 & Jaffna & Jaffna & Kolikuttu & Used for domestic consumption \\
14 & Angunukolapalassa & Hambanthota & Kolikuttu & Fusarium wilt Susceptible plant \\
15 & HORDI & Gannoruwa (Kandy) & Ambul & Control \\
\hline
\end{tabular}

Quantification of DNA was done using 260nm and $280 \mathrm{~nm}$ wave lengths in UV spectrophotometer by diluting the stock solution. Finally, a sample of the stock was diluted to $50 \mathrm{ng} / \mu 1$ to be used in PCR.

PCR amplification was carried out with six simple sequence repeats (SSR) primers (Table2). Final concentration in the reaction solution was $0.5 \mathrm{pM}$ for each forward and reverse primer, $0.2 \mathrm{mM}$ for dNTPs each, $2.5 \mathrm{mM}$ for $\mathrm{MgCl}_{2}$ and $0.025 \mathrm{U} / \mu \mathrm{l}$ of Taq DNA polymerase (Promega Corporation, USA) and $50 \mu \mathrm{g} / \mu \mathrm{l}$ of DNA template in a $15 \mathrm{ul}$ reaction volume.

PCR was performed using $94^{0} \mathrm{C}$ for $2 \mathrm{~min}$ for the initial denaturing and then 35 cycles of $(30 \mathrm{sec}$ $94^{\circ} \mathrm{C}$ denaturing, $30 \mathrm{sec}$ at annealing temperature $55^{\circ} \mathrm{C}, 30$ seconds $72^{\circ} \mathrm{C}$ extension) and a final extension at $72^{\circ} \mathrm{C}$ for $5 \mathrm{~min}$ for primers MaSSR 18 , MaSSR 20 and MaSSR 24. As the annealing temperatures of the primers Mb1-134, Mb1-113 and $\mathrm{Mb} 1-69$ ranged from $59^{\circ} \mathrm{C}$ to $62^{\circ} \mathrm{C}$, two categories of touchdown temperature cycles were used, con- sisting of initial denaturation of $3 \mathrm{~min}$ at $95^{\circ} \mathrm{C}$ for both profiles, followed by five cycles reduced by $1^{0} \mathrm{C}$ per cycle (either $60-55^{\circ} \mathrm{C}$ or $55-45^{\circ} \mathrm{C}$ ), culminating with 30 cycles of denaturation for $20 \mathrm{~s}$ at $94^{\circ} \mathrm{C}$, annealing for $20 \mathrm{~s}$ at either 56 or $48^{\circ} \mathrm{C}$ respectively, extension for $30 \mathrm{~s}$ at $72^{\circ} \mathrm{C}$, and a final extension at $72^{\circ} \mathrm{C}$ for $10 \mathrm{~min}$ (Buhariwalla et al., 2005).

Eight percent polyacrylamide $40 \mathrm{~cm}$ gels containing $7 \mathrm{M}$ urea in $0.5 \times \mathrm{TBE}$ were prepared. The gel was pre run at (at 50 W) for 45-60 min to prewarm to $45^{\circ} \mathrm{C}$. Six micro liters of products were run at $1300 \mathrm{~V}$ for about one and half hours and at $1500 \mathrm{v}$ for about three hours for efficient separation of bands. After electrophoresis, the gels were soaked in $10 \%$ acetic acid for $20 \mathrm{~min}$, washed 3 times for $3 \mathrm{~min}$ each in deionized water and stained for $20 \mathrm{~min}$ in $0.1 \% \mathrm{AgNO}_{3}$ containing $0.15 \%$ formaldehyde. After a brief rinse $(5 \mathrm{sec})$ in de-ionized water signals were developed by soaking the gels in $500 \mathrm{ml}$ of $7.5 \%$ solution of $\mathrm{NaOH}$ and $3.75 \mathrm{ml}$ formaldehyde. Development was terminated by soaking gels in

Table 2. Six SSR primers used in the analysis

\begin{tabular}{|c|c|c|c|}
\hline Primer pair & Sequence of 5' to 3'primer pairs & Annealing Temperature & Expected Product size (bp) \\
\hline MaSSR 18a (F) & CGTCACAGAAGAAAGCACTTG & $55^{0} \mathrm{C}$ & 200 \\
\hline MaSSR 18b (R) & ССТTСТССАTCGTCATCAATC & & \\
\hline MaSSR 20a (F) & GAAATGGAGTTGGAGAAACA & $55^{\circ} \mathrm{C}$ & 222 \\
\hline MaSSR 20b (R) & CACATATCCTTGTCGGAAGT & & \\
\hline MaSSR 24a (F) & GACCCCCTTAAGCTGAACA & $55^{\circ} \mathrm{C}$ & 172 \\
\hline MaSSR 24b (R) & CCGACGGTCAACATACAATACA & & \\
\hline $\mathrm{Mb} 1-69 \mathrm{a}(\mathrm{F})$ & CTGCCTCTCCTTCTCCTTGGAA & $48^{\circ} \mathrm{C}$ & 386 \\
\hline Mb1-69b (R) & TCGGTGATGGCTCTGACTCA & & \\
\hline Mb1-113a (F) & AGGTGCCACACAGTTCAGACA & $56{ }^{\circ} \mathrm{C}$ & 399 \\
\hline Mb1-113b (R) & CAACCCAAACCTGTTCGACCAA & & \\
\hline Mb1-134a (F) & ATGCCCAAGAAGGGAAGGGAA & $56^{\circ} \mathrm{C}$ & 398 \\
\hline $\mathrm{Mb} 1-134 \mathrm{~b}(\mathrm{R})$ & TAATGCCGGAGGATCAGTGTGA & & \\
\hline
\end{tabular}

F- Forward; R- Reverse

Source: Samarasinghe et al., 2002 and Buhariwalla et al., 2005 


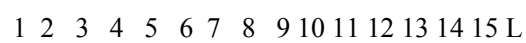

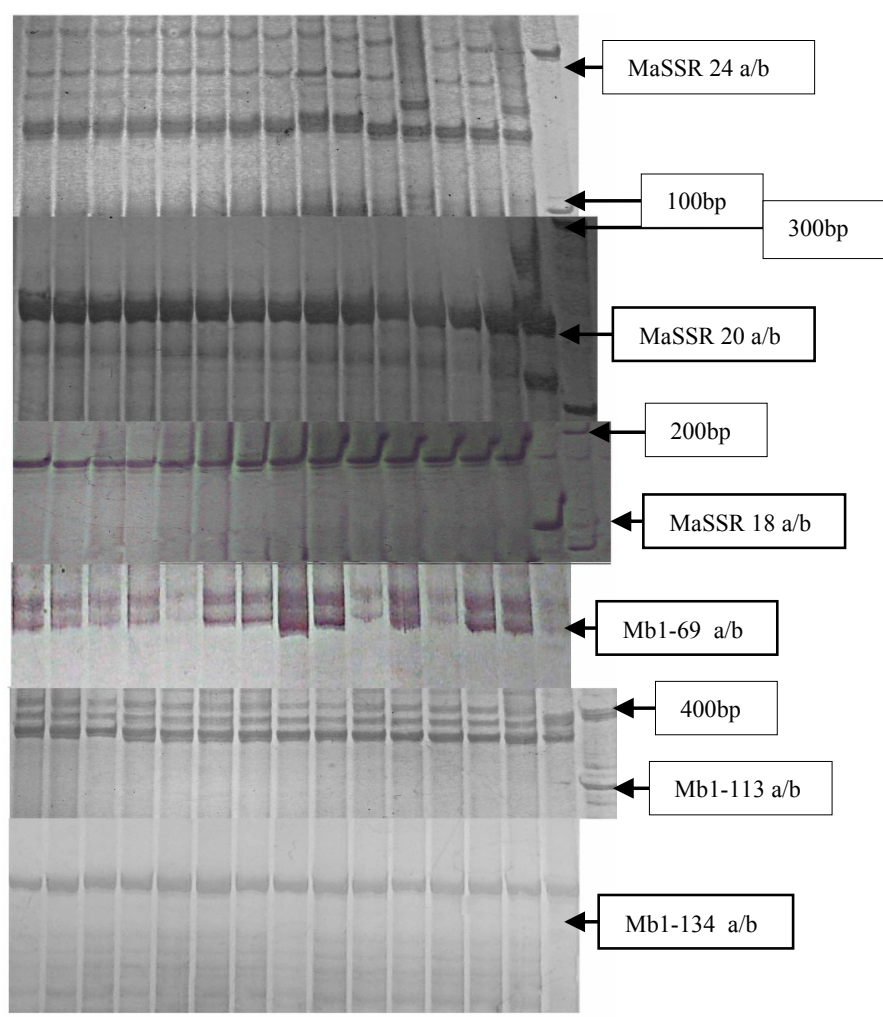

Plate 1: Polyacrylamide gel ( $8 \%$ ) picture of the SSR products of 14 "Kolikuttu" accessions and "Ambul" accession amplified by six primers- [Sample descriptions of lane 1-15 are given in Table 1]

$10 \%$ acetic acid for 2-3min. Finally, gels were rinsed with de-ionized water.

Each polyarylamide gel was scored visually for each primer and data were analyzed using POPGENE version 1.32. Presence of a band scored as " 1 " and absence of a band scored as " 0 " whereas non amplified bands were considered as missing data and denoted as ".' for the software.

Three different Kolikuttu genotypes were identified among examined accessions. The accession known as "Athdath Puwalu" collected from Puttlam area (Genetic distances with the accession 11 is 0.1112 , with the accession 12 is 0.3054 and with the control is 0.9985 ) is clustered separately while the accession collected from Telijjawila also is shown as a different genotype (Genetic distances with the accession 13 is 0.1719 and with the control is 0.4595) (Table 3) whereas accessions known as "Kutti Puwalu" , "Idal Puwalu" and "Kotiyagala type" have included in the same group (Fig. 1).

Accession collected from Angunakolapelassa which had not affected from Fusarium wilt is unique genotype clustered separately from other Fusarium wilt tolerant accessions. The accession known as "Agra" collected from Telijjawila is a newly released variety [by Dr. (Mrs) Sujatha Weerasinghe of Agriculture Research station, Teli-

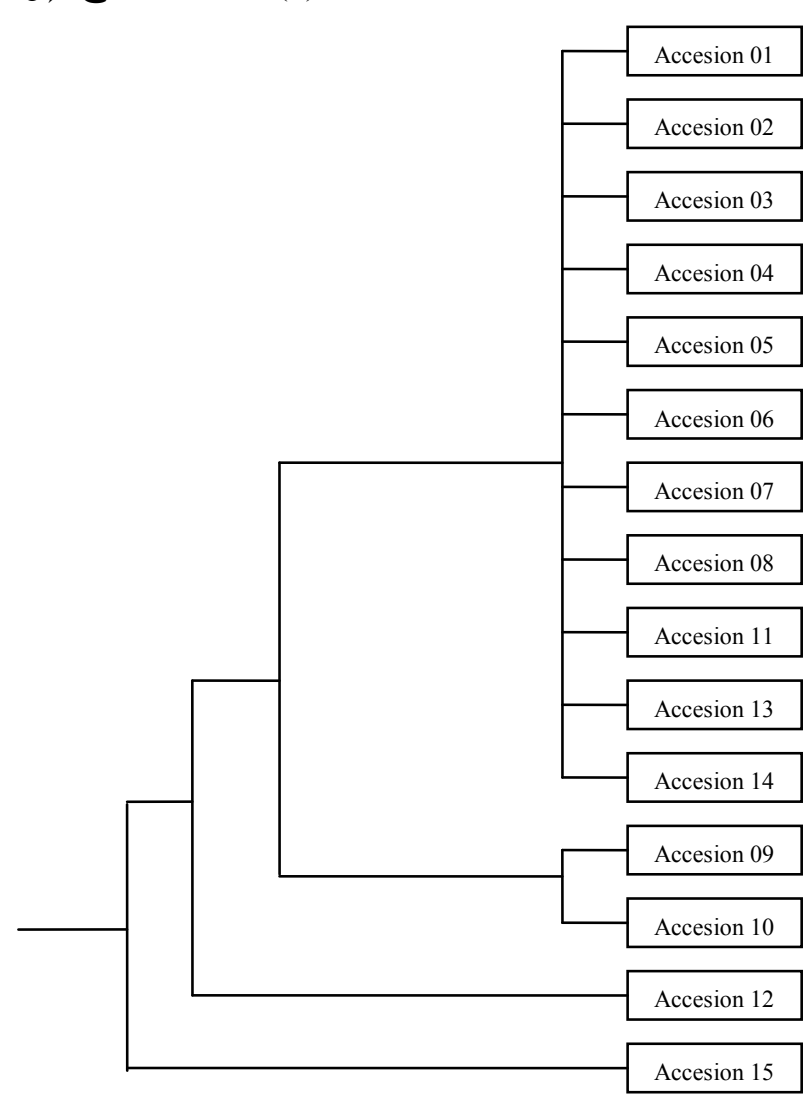

Figure 1. Hierarchical cluster tree (Dendrogram) indicates grouping among accessions

[Note: Accessions 1-5 HoRDI collection, 6-Idal puwalu, 7- Kutti puwalu, 8-Kotiyagala type, 9- Athdath puwalu, 10- PGRC[Plant Genetic Resources Centre]

(Angunakolapalessa), 11- Agra, 12- Tellijjawila, 13- Jaffna, 14- Fusarium wilt susceptible, 15-Control(Ambul)

jjawila, Matara] with neither hard lump formation in fruits nor affected by Fusarium wilt over ten generations. But it has not shown a genetic variation at analyzed SSR loci with reference to either morphological variation or Fusarium wilt tolerance (Fig. 1). Accessions 1 to 5 were collected from Horticultural Research and Development Institute (HORDI) to evaluate Fusarium wilt disease tolerance. However, they have clustered together with Fusarium wilt susceptible accession (accession No. 14) and therefore, a clear relationship between these two types could not obtain and further investigations are needed.

Among the analyzed SSR primers, MaSSR $24 \mathrm{a} / \mathrm{b}$ was the best primer for genotyping "Kolikuttu" accessions. Despite a considerable morphological variation observed, analyzed accessions showed a lower genetic variation with respect to the analyzed SSR loci. This concludes that the most of the morphological variations in 'Kolikuttu' were due to the environmental effect than the genetic effect.

However, three different genotypes were identified among examined Kolikuttu accessions which 
Table 3: Nei's pairwise Genetic Distances (1972)

\begin{tabular}{lccccccccccccccccc}
\hline pop ID & $\mathbf{1}$ & $\mathbf{2}$ & $\mathbf{3}$ & $\mathbf{4}$ & $\mathbf{5}$ & $\mathbf{6}$ & $\mathbf{7}$ & $\mathbf{8}$ & $\mathbf{9}$ & $\mathbf{1 0}$ & $\mathbf{1 1}$ & $\mathbf{1 2}$ & $\mathbf{1 3}$ & $\mathbf{1 4}$ & $\mathbf{1 5}$ & \\
\hline 1 & $* * * *$ & 1.0000 & 1.0000 & 1.0000 & 1.0000 & 1.0000 & 1.0000 & 1.0000 & 0.8947 & 0.8947 & 1.0000 & 0.8421 & 1.0000 & 1.0000 & 0.4737 & \\
2 & 0.0000 & $* * * *$ & 1.0000 & 1.0000 & 1.0000 & 1.0000 & 1.0000 & 1.0000 & 0.8947 & 0.8947 & 1.0000 & 0.8421 & 1.0000 & 1.0000 & 0.4737 & \\
3 & 0.0000 & 0.0000 & $* * * *$ & 1.0000 & 1.0000 & 1.0000 & 1.0000 & 1.0000 & 0.8947 & 0.8947 & 1.0000 & 0.8421 & 1.0000 & 1.0000 & 0.4737 & \\
4 & 0.0000 & 0.0000 & 0.0000 & $* * * *$ & 1.0000 & 1.0000 & 1.0000 & 1.0000 & 0.8947 & 0.8947 & 1.0000 & 0.8421 & 1.0000 & 1.0000 & 0.4737 \\
5 & 0.0000 & 0.0000 & 0.0000 & 0.0000 & $* * * *$ & 1.0000 & 1.0000 & 1.0000 & 0.8947 & 0.8947 & 1.0000 & 0.8421 & 1.0000 & 1.0000 & 0.4737 \\
6 & 0.0000 & 0.0000 & 0.0000 & 0.0000 & 0.0000 & $* * * *$ & 1.0000 & 1.0000 & 0.8947 & 0.8947 & 1.0000 & 0.8421 & 1.0000 & 1.0000 & 0.4737 \\
7 & 0.0000 & 0.0000 & 0.0000 & 0.0000 & 0.0000 & 0.0000 & $* * * *$ & 1.0000 & 0.8947 & 0.8947 & 1.0000 & 0.8421 & 1.0000 & 1.0000 & 0.4737 \\
8 & 0.0000 & 0.0000 & 0.0000 & 0.0000 & 0.0000 & 0.0000 & 0.0000 & $* * * *$ & 0.8947 & 0.8947 & 1.0000 & 0.8421 & 1.0000 & 1.0000 & 0.4737 \\
9 & 0.1112 & 0.1112 & 0.1112 & 0.1112 & 0.1112 & 0.1112 & 0.1112 & 0.1112 & $* * * *$ & 1.0000 & 0.8947 & 0.7368 & 0.8947 & 0.8947 & 0.3684 \\
10 & 0.1112 & 0.1112 & 0.1112 & 0.1112 & 0.1112 & 0.1112 & 0.1112 & 0.1112 & 0.0000 & $* * * *$ & 0.8947 & 0.7368 & 0.8947 & 0.8947 & 0.3684 \\
11 & 0.0000 & 0.0000 & 0.0000 & 0.0000 & 0.0000 & 0.0000 & 0.0000 & 0.0000 & 0.1112 & 0.1112 & $* * * *$ & 0.8421 & 1.0000 & 1.0000 & 0.4737 \\
12 & 0.1719 & 0.1719 & 0.1719 & 0.1719 & 0.1719 & 0.1719 & 0.1719 & 0.1719 & 0.3054 & 0.3054 & 0.1719 & $* * * *$ & 0.8421 & 0.8421 & 0.6316 \\
13 & 0.0000 & 0.0000 & 0.0000 & 0.0000 & 0.0000 & 0.0000 & 0.0000 & 0.0000 & 0.1112 & 0.1112 & 0.0000 & 0.1719 & $* * * *$ & 1.0000 & 0.4737 \\
14 & 0.0000 & 0.0000 & 0.0000 & 0.0000 & 0.0000 & 0.0000 & 0.0000 & 0.0000 & 0.1112 & 0.1112 & 0.0000 & 0.1719 & 0.0000 & $* * * *$ & 0.4737 & \\
15 & 0.7472 & 0.7472 & 0.7472 & 0.7472 & 0.7472 & 0.7472 & 0.7472 & 0.7472 & 0.9985 & 0.9985 & 0.7472 & 0.4595 & 0.7472 & 0.7472 & $* * * *$ & \\
\hline
\end{tabular}

[Nei's genetic identity (above diagonal) and genetic distance (below diagonal)]

will be useful in variety improvement. The accession located at Angunakolapallessa can be considered as an important genotype for further evaluation for Fusarium wilt tolerance. Analyzing these samples with more primers may help for further genotyping.

\section{ACKNOWLEDGEMENT}

The authors wish to thank Prof. Rohan Rajapakse, Dr (Mrs.) Sudarshanee Geekiyanage, Dr (Mrs.) Disna Rathnasekara, Dr RGAS Rajapakse, Dr (Mrs.) Sujatha Weerasinghe, Dr (Mrs.) Manel Dassanayake, and Mr Mahesh T Gunasena for their valuable suggestions given during this study. Also the assistance given by Miss SLD Jayaweera, Research Assistant is kindly acknowledged.

\section{REFERENCES}

AgStat 2004. Agricultural Statistics, Socio - Economic and Planning Center. Department of Agriculture, Peradeniya

Buhariwalla HK, Jarret RL, Jayashree B, Crouch J $\mathrm{H}$ and Ortiz R 2005 Isolation and characterization of microsatellite markers from Musa balbisiana. Molecular Ecology Notes. Backwell Publishing Ltd 5: 327-330

Chandraratna MF and Nanayakkara KDSS 1951 Cultivated varieties of banana in Ceylon. Tropical Agriculturist. 107:70-91
Chandraratna MF 1951 The origin of cultivated races of banana, Indian journal of genetic \& breeding. 11:29-33

Crouch HK, Crouch JH, Jarret RL, Cregan PB and Ortiz R 1998 Microsatellite Loci in Haploid and Diploid Gametes of Musa in Cell Biology \& Molecular Genetics. CROP SCIENCE. 38: 212

Rajapakse RGAS, Sakalasuriya SMISK, Kahawatta J, Sumanapala RV and Edirimanna ERSP 2005 Identification of races of Fusarium wilt pathogen of Banana in Sri Lanka and selection of resistant germplasm. Annals of the Sri Lanka Department of agriculture. 7:225-232.

Samarasinghe WLG, Rukshanthi JPD, Nahfees AM, Muhunthan R and Perera ALT 2001 A Laboratory Manual on DNA typing using RAPD \& SSR technologies with silver stained PAGE. PGIA, Unversity of Peradeniya. pp.122

Samarasinghe WLG, Perera ALT, Wickramasinghe IP and Nafees AM 2002 Molecular Characterization of Musa spp. by Simple Sequence Repeats (SSR). Tropical Agricultural Research. Center for Plant Molecular Biology, India 14:110.

Weising K, Nybom H, Wolff K and Meyer W 1995 DNA Fingerprinting in Plants and Fungi. CRC Press Inc. 